\title{
SINDROME DE STEVEN-JOHNSON EM CRIANÇA APOS O USO DE FENOBARBITAL
}

\section{Pôster}

Autores deste trabalho:

PRISCILA BECHAALANI: IAMSPE- HOSPITAL SERVIDOR PÚBLICO ESTADUAL DE SÃO PAULO

MARIA ELISA BERTOCCO ANDRADE: IAMSPE- HOSPITAL SERVIDOR PÚBLICO ESTADUAL DE SÃO PAULO

ELIANA RODRIGUES BIAMINO: IAMSPE- HOSPITAL SERVIDOR PÚBLICO ESTADUAL DE SÃO PAULO

TATIANA LEITE SARAIVA: IAMSPE- HOSPITAL SERVIDOR PÚBLICO ESTADUAL DE SÃO PAULO

Karla Michely Inacio de Carvalho: IAMSPE- HOSPITAL SERVIDOR PÚBLICO ESTADUAL DE SÃO PAULO

JOÃO FERREIRA MELLO: IAMSPE- HOSPITAL SERVIDOR PÚBLICO ESTADUAL DE SÃO PAULO

Área do Trabalho: Pediatria

Número de inscrição: 5584

Data da submissão:30/08/2016 às 15:17

\section{Justificativa}

Importante ressaltar este caso pela apresentação atípica da síndrome e a história pregressa de reação pelo mesmo fármaco.

\section{Objetivo(s)}

Relatar um caso de uma criança que apresentou uma reação grave ao Fenobarbital.

\section{Método(s)}

Relatar o caso de uma criança com síndrome de Steven-Johnson relacionado ao fenobarbital, segundo critérios de diagnóstico da mesma.

\section{Resultado(s)}


L.F.C.S, sexo masculino, 4 anos, antecedente de autismo e epilepsia, em uso de ácido valpróico há 1 ano, e fenobarbital há 1 mês, foi internado por quadro de febre há um dia, acompanhada de exantema em região malar bilateral, erupção máculo-papular em tronco, dorso e membros, não pruriginosas, lesões ulceradas em mucosa oral e palato, edema e crostas em lábios. Foi suspenso o fenobarbital (droga mais recente) e prescrito metilprednisolona e higiene oral. Na evolução, apresentou piora progressiva das lesões com descamação em regiões malar, perioral e em parte superior do corpo e desidratação por restrição hídrica e alimentar sendo transferido á UTI e prescrito imunoglobulina humana intravenosa e suporte alimentar e hídrico por sonda. Após 2 dias, evoluiu com lesões bolhosas restritas em face, com destacamento cutâneo inferior a 10\%, e após 17 dias do quadro inicial, houve regressão total das lesões. Na internação, foi realizado avaliação da imunidade com valores das imunoglobulinas normais; biópsia de lábio inferior com mucosite crônica espongiótica com numerosos focos de disceratose sendo favorável a lesão induzida por fármacos, o hemograma com anemia normocítica e discreta leucocitose, sem alteração de função renal, hepática e sorologias.

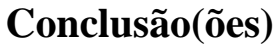

O fármaco implicado neste caso de farmacodermia grave, confirmada por biópsia, foi o fenobarbital, considerado na literatura um dos mais frequentes desencadeantes. Importante ressaltar, que esta apresentação atípica, sugerindo inicialmente um quadro de exantema viral com estomatite pode retardar o diagnóstico e tratamento, modificando o prognóstico. O uso da imunoglobulina humana intravenosa tem sido indicado em estudos sobre o tratamento desta síndrome, com evidências de melhorar o prognóstico, o que comprovamos neste caso. O paciente apresentava antecedente de reação cutânea a este fármaco no primeiro ano de vida, não correlacionado na ocasião. Com isto, destacamos a importância da história clínica pregressa detalhada para a suspeita de diagnóstico das farmacodermias. 